\title{
PENERAPAN MANAJEMEN MUTU EKSTRAKURIKULER KARYA ILMIAH DI SMA MUHAMMADIYAH 1 TAMAN SIDOARJO
}

\author{
M. Nashiiruddin Addaa'I \& Akhtim Wahyuni \\ Universitas Muhammadiyah Sidoarjo \\ nashiiruddin@gmail.com , awahyuni@umsida.ac.id
}

\begin{abstract}
The success of extracurricular activities depends on quality or quality management or management processes. Therefore, this study aims to describe the application of quality management for extracurricular activities of teenage scientific papers including planning, implementation and evaluation activities in order to get customer satisfaction, be able to optimize aspects of everyone, carry out fact-based management and make continuous improvements. The research method used is descriptive qualitative research through observation, interviews and documentation. This research was conducted at SMA Mubammadiyah 1 Taman, which one of the visions is excellent academic quality. The application of extracurricular quality management of youth science consists of planning activities including customer involvement in the selection of supervisors to planning work programs that can be carried out and always carrying out joint evaluations, implementing activities including the involvement of each student in scientific competitions at regional, national and international levels, as well as evaluation activities. through discussion and project improvement and more intensive coaching. The application is adjusted to the quality management principle of Edward Sallis known as total quality management, namely customer satisfaction, aspects of everyone, management based on facts and continuous improvement which results in increased extracurricular achievements of scientific work in scientific competitions that are followed. The conclusion of this study is the application of extracurricular quality management of youth science consisting of planning, implementation and evaluation activities on the basis of quality management in the form of customer satisfaction, aspects of everyone, fact-based management and continuous improvement.
\end{abstract}

Keywords: Quality Management, Extracurricular Activity, Youth Science

\begin{abstract}
Abstrak : Keberhasilan kegiatan ekstrakurikuler bergantung pada pengelolaan atau proses manajemen yang berkualitas atau bermutu. Oleh karena itu penelitian ini bertujuan untuk mendeskripsikan penerapan manajemen mutu kegiatan ekstrakurikuler karya ilmiah remaja meliputi kegiatan perencanaan, pelaksanaan hingga evaluasi untuk bisa mendapatkan kepuasan pelanggan, bisa mengoptimalkan aspek terhadap setiap orang, melaksanakan manajemen berdasarkan fakta serta melakukan perbaikan berkesinambungan. Metode penelitian yang digunakan adalah penelitian deskriptif kualitatif melalui observasi, wawancara dan dokumentasi. Penelitian ini dilaksanakan di SMA Muhammadiyah 1 Taman yang salah satu visinya adalah excellent academic quality atau pelayanan akademis yang berkualitas. Penerapan manajemen mutu ekstrakurikuler karya ilmiah terdiri dari kegiatan perencanaan meliputi pelibatan pelanggan dalam pemilihan pembina hingga perencanaan program kerja yang bisa dilakukan dan senantiasa melaukan evaluasi bersama, kegiatan pelaksanaan meliputi keterlibatan setiap peserta didik dalam kompetisi ilmiah baik tingkat regional, nasional maupun internasional, serta kegiatan evaluasi melalui diskusi dan perbaikan project serta
\end{abstract}

Manazhim : Jurnal Manajemen dan Ilmu Pendidikan

Volume 2, Nomor 2, Agustus 2020; 172-181

https://ejournal.stitpn.ac.id/index.php/manazhim 
pembinaan yang lebih intensif. Penerapan tersebut disesuaikan dengan prinsip manajemen mutu dari Edward Sallis yang dikenal dengan total quality management yaitu kepuasan pelanggan, aspek terhadap setiap orang, manajemen berdasarkan fakta dan perbaikan berkesinambungan yang menghasilkan peningkatan prestasi ekstrakurikuler karya ilmiah di kompetisi-kompetisi ilmiah yang diikuti. Kesimpulan dari penelitian ini adalah penerapan manajemen mutu ekstrakurikuler karya ilmiah terdiri dari kegiatan perencanaan, pelaksanaan dan evaluasi dengan dasar manajemen mutu berupa kepuasan pelanggan, aspek terhadap setiap orang, manajemen berdasarkan fakta dan perbaikan berkesinambungan.

Kata Kunci : Manajemen Mutu, Kegiatan Ekstrakurikuler, Karya Ilmiah Remaja

\section{PENDAHULUAN}

Peningkatan kualitas manusia dapat dicapai melalui sebuah proses yang biasa kita sebut dengan proses pendidikan. Pendidikan sebagai bagian dari proses memiliki dua kegiatan utama yaitu kegiatan intrakurikuler yang memiliki standart berupa kurikulum pendidikan nasional serta kegiatan ekstrakurikuler berupa pengembangan bakat dan minat siswa dalam berbagai bidang seperti kerohanian, keolahragaan, seni, olimpiade, penelitian, maupun Bahasa ${ }^{1}$. Kegiatan ekstrakurikuler menjadi sebuah kebutuhan di zaman millennial ini karena lulusan saat ini diharapkan tidak hanya cakap dalam keilmuan melainkan harus cakap dalam keterampilan. Oleh karena itu kegiatan ekstrakurikuler menjadi bagian penting dalam proses pendidikan untuk bisa melengkapi kegiatan intrakurikuler yang rutin dilaksanakan setiap jam pelajaran. Ada banyak faktor yang mempengaruhi keberhasilan kegiatan ekstrakurikuler suatu lembaga pendidikan, diantaranya adalah kesiapan fasilitas atau sarana pra sarana yang memadai, adanya tenaga ahli sebagai pelatih atau mentor para siswa, serta proses penelusuran potensi siswa yang tertata dengan baik $^{2}$.

Kegagalan dalam pelaksanaan kegiatan ekstrakurikuler berasal dari kegiatan manajemen yang tidak terlaksana dengan baik. Oleh karena itu perlu adanya manajemen atau pengelolaan pendidikan baik kegiatan intrakurikuler maupun kegiatan ekstrakurikuler yang baik untuk mengembangkan potensi siswa supaya

\footnotetext{
${ }^{1}$ Abd. Mukhid, 'Meningkatkan Kualitas Pendidikan Melalui Sistem Pembelajaran Yang Tepat', Tadris, 2.1 (2007), 120-33.

${ }^{2}$ Yayan Inriyani, Wahjoedi Wahjoedi, and Sudarmiatin Sudarmiatin, 'Peran Kegiatan Ekstrakurikuler Untuk Meningkatkan Prestasi Belajar IPS', Prosiding Seminar Nasional Mahasiswa Kerjasama Direktorat Jenderal Guru Dan Tenaga Kependidikan Kemendikbud, 1 (2016), 1-7

$<$ https://doi.org/http://pasca.um.ac.id/conferences/index.php/gtk/article/download/246/233>.
} 
semakin berkembang dan mendapatkan prestasi yang diharapkan ${ }^{3}$. Manajemen atau pengelolaan yang baik perlu memperhatikan proses perbaikan yang terstruktur supaya luaran yang dihasilkan sesuai dengan yang diharapkan dalam hal ini bisa kita kenal dengan manajemen mutu. Berkaitan dengan hal itu maka penelitian ini berfokus pada manajemen mutu ekstrakurikuler karya ilmiah dengan merujuk pada teori manajemen mutu dari Edward Sallis meliputi kepuasan pelanggan, aspek terhadap setiap orang, manajemen berdasarkan fakta dan perbaikan berkesinambungan. yang dikenal dengan Total Quality Manajemen ${ }^{4}$.

Dalam penelitian ini penulis mengambil sampel penelitian di SMA Muhammadiyah 1 Taman Sidoarjo terutama dalam penerapan manajemen ekstrakurikuler karya ilmiah remaja. Hal tersebut dikarenakan terdapat beberapa hal yang mendukung manejemen mutu ekstrakurikulernya karya ilmiah di SMA Muhamamdiyah 1 Taman yaitu dukungan kebijakan pimpinan sekolah, dukungan walimurid dalam hal moril maupun materi, serta adanya sarana prasarana yang mendukung ekstrakurikuler karya ilmiah. Penelitian ini bertujuan untuk mendeskripsikan penerapan manajemen mutu kegiatan ekstrakurikuler karya ilmiah remaja meliputi kegiatan perencanaan, pelaksanaan hingga evaluasi untuk bisa mendapatkan kepuasan pelanggan, bisa mengoptimalkan aspek terhadap setiap orang, melaksanakan manajemen berdasarkan fakta serta melakukan perbaikan berkesinambungan.

\section{METODE PENELITIAN}

Penelitian ini menggunakan jenis penelitian deskriptif kualitatif yang dilaksanakan di SMA Muhamamdiyah 1 Taman terutama berfokus pada manajemen mutu karya ilmiah remaja. Pengumpulan data yang digunakan dalam penelitian ini meliputi observasi, wawancara dan dokumentasi. Observasi dan dokumentasi dilaksanakan secara langsung di lapangan, sedangkan wawancara dilakukan pada pihak-pihak yang berhubungan dengan kegiatan ekstrakurikuler karya ilmiah. Data

\footnotetext{
${ }^{3}$ Mohamad Mustari and others, Manajement Pendidikan, RajaGrafika Persada, 2014.

${ }^{4}$ Edward Sallis, Total Quality Management in Education: Third Edition, Total Quality Management in Education: Third Edition, 2014 < https://doi.org/10.4324/9780203417010>.
} 
yang terkumpul selanjutnya akan dianalisa melalui tahap reduksi data, penyajian data dan penegasan kesimpulan.

\section{HASIL DAN PEMBAHASAN}

Islam merupakan agama yang sempurna dan senantiasa mengajarkan umatnya untuk melakukan sesuatu secara bersungguh-sungguh dan bertanggung jawab sebagaimana dapat dilihat dalam QS. Al-Zalzalah ayat 7-8 yang menekankan nilai tanggung jawab (akuntabilitas) dimana setiap perbuatan akan ada balasan yang sesuai ${ }^{5}$. Selain itu juga harus dilakukan secara rapi dan teratur atau sistematis karena sebuah perencanaan yang baik serta dilaksanakan dengan baik akan menghasilakan sesuatu yang baik. Hal tersebut saat ini biasa dikenal dengan manajemen mutu dimana sebuah proses yang terstruktur akan menghasilkan luaran seperti yang diharapkan.

Manajemen mutu menurut Edward Sallis dalam buku Total Quality Management (TQM) merupakan sebuah filosofi tentang perbaikan secara terus menerus, yang dapat memberikan seperangkat alat praktis kepada setiap institusi pendidikan dalam memenuhi kebutuhan, keinginan, dan harapan para pelanggannya, saat ini dan untuk masa yang akan datang ${ }^{6}$. Sedangkan apabila kita mengikuti paradigma UU SISDIKNAS 2003 maka kebijakan mutu didasarkan pada sistem penjaminan mutu terpadu yang akhirnya berujung pada perbaikan terus menerus atau berkesinambungan ${ }^{7}$. Oleh karena itu manajemen mutu merupakan pengangan yang harus diperhatikan oleh setiap lembaga pendidikan dalam membangun pendidikan yang berkelanjutan yang berhubungan dengan pelanggan dimana hal tersebut dimulao dari mulai dari kepuasan pelanggan, aspek terhadap setiap orang, manajemen berdasarkan fakta dan perbaikan berkesinambungan ${ }^{8}$.

\footnotetext{
${ }^{5}$ Adi Supriyanto, 'Apa Makna Yang Terkandung Di Dalam Surat Az Zalzalah', Https://Www.Dictio.Id, 2018.

${ }^{6}$ Sallis.

${ }^{7}$ A. Hanief Saha Ghafur, Manajemen Penjaminan Mutu Perguruan Tinggidi Indonesia: Suatu Analisis Kebijakan (Jakarta: Bumi Aksara, 2008).

${ }^{8}$ Syarifuddin Syarifuddin, 'Total Quality Manajement (TQM) Sebagai Manajemen Mutu Alternatif

Pada Program Studi Pendidikan Bahasa Arab', Http:/ /E-Journal.Iain-Palangkaraya.Ac.Id, 2011, 21-34.
} 
Penelitian ini dilaksanakan di SMA Muhammadiyah 1 Taman dimana di sekolah ini memiliki tiga pilar utama yang menjadi visi sekolah dimana salah satu pilarnya berfokus pada excellent academic quality atau kualitas akademis yang baik ${ }^{9}$. Pilar tersebut merupakan upaya sekolah untuk ikut serta dalam mencerdaskan kehidupan bangsa melalui kesungguhan dan pengelolaan yang sistematis dengan memperbaiki dan meningkatkan kualitas akademik serta memadukan antara kurikulum yang sesuai dengan layanan fasilitas penunjang pembelajaran yang representatif. Dalam penelitian ini akan dibahas secara detail penerapan manajemen mutu ekstrakurikuler karya ilmiah remaja meliputi perencanaan, pelaksanaan dan evaluasi serta merujuk teori Total Quality Management (TQM) karya Edward Sallis mulai dari kepuasan pelanggan, aspek terhadap setiap orang, manajemen berdasarkan fakta dan perbaikan berkesinambungan.

\section{Perencanaan Manajemen Mutu Ekstrakurikuler Karya Ilmiah di SMA Muhammadiyah 1 Taman}

a. Aspek kepuasan pelanggan dalam tahap perencanaan manajemen mutu ekstrakurikuler karya ilmiah di SMA Muhammadiyah 1 Taman dimulai dari pemilihan pembina ekstrakulikuler karya ilmiah remaja didasari oleh masukan dari siswa.

b. Aspek terhadap setiap orang dilaksanakan melalui penyusunan program kerja ekstrakulikuler karya tulis SMA Muhammadiyah 1 Taman yang melibatkan anggota ekstrakulikuler karya tulis untuk memberikan masukan dengan menggunakan angket.

c. Manajemen berdasarkan fakta dilakukan melalui pembagian surat keputusan dari sekolah dalam pengangkatan pembina ekstrakurikuler karya ilmiah hingga peresmian anggota ekstra beserta penjadwalan program kerjanya.

d. Aspek perbaikan berkesinambungan juga dipertimbangkan oleh koordinator dan pembina dalam penyusunan program kerja ekstrakulikuler karya tulis dengan cara memperbaiki kesalahan dan target yang belum tercapai pada program kerja tahun sebelumnya.

9 Smamita, 'Visi Misi SMA Muhamamdiyah 1 Taman', Smamita.Ac.Id, 2018. 


\section{Pelaksanaan Manajemen Mutu Ekstrakurikuler Karya Ilmiah}

a. Kepuasan pelanggan dilaksanakan melalui pelayanaan akademis yang berkualitas dalam manajemen mutu ekstrakurikuler karya ilmiah remaja. Pelayanan manajemen mutu ekstrakurikuler karya ilmiah kepada peserta didik meliputi tahap pemetaan potensi peserta didik, pembinaan rutin, pelatihan penelitian ilmiah, pelatihan kepenulisan ilmiah, pelatihan presentasi ilmiah, hingga partisipasi dalam kompetsisi baik skala regional, nasional hingga internasional. Selain itu adanya komunikasi yang baik dari pembina ekstrakurikuler karya ilmiah dengan wali murid terhadap tim ekstrakurikuler karya ilmiah sangat menunjang pengembangan potensi peserta didik dan pencapaian prestasi yang bisa diraih. Hal tersebut juga menunjukkan adanya kepuasan pelanggan internal dari pihak wali murid.

b. Aspek terhadap setiap orang merupakan sebuah acuan suatu keberhasilan Total Quality Manajemen yang ada di SMA Muhammadiyah 1 Taman. Target yang telah diinginkan oleh wakil kepala sekolah bagian kesiswaan semua peserta didik mempunyai tahapan-tahapan yang jelas. Dari hasil wawancara yang dilakukan target yang ingin dicapai adalah tim karya tulis ilmiah mendapatkan prestasi ditingkat regional, nasional, bahkan tingkat internasional pastinya target tim karya ilmiah secara bertahap.

c. Manajemen berdasarkan fakta yang dimaksud dalam Total Quality Manajemen adalah koordinator ekstrakurikuler melakukan pengamatan melalui pendataan surat keputusan pembina ekstrakurikuler, program pembinaan, dan data target prestasi karya ilmiah. Juga ada program pembinaan untuk menghasilkan produk peserta didik. Dari pemaparan dengan koordinator ekstrakurikuler pembina karya ilmiah selalu dimonitoring sesuai arahan dari pimpinan sekolah bagian kesiswaan. Setiap tim akan selalu mendapatkan suport dari sekolah ketika mengikuti kompetisi yang akan diikuti mulai dari uang pendaftaran, konsumsi, biaya transportasi dan biaya konsumsi. Bahkan sebelum menuju tempat kompetisi semua tim karya ilmiah dan pembina ekstrakulikuler karya ilmiah mendapatkan motivasi dari koordinator ekstrakurikuler.

d. Perbaikan berkesinambungan menjadi perhatian bagi pimpinan sekolah terhadap semua pihak yang terlibat dalam ektrakurikuler karya ilmiah remaja 
terkait prestasi yang diperoleh. Apakah sudah sesuai dengan target dan program kerja pembina ekstrakurikuler karya ilmiah. Perbaikan selalu dilakukan untuk menghasilkan hasil yang diinginkan.

\section{Evaluasi Manajemen Mutu Ekstrakurikuler Karya Ilmiah di SMA Muhammadiyah 1 Taman}

a. Kepuasan pelanggan dinilai dari evaluasi terhadap kepercayaan dari pelanggan dalam hal ini adalah wali murid diman dengan memperlihatkan perkembangan potensi diri dan prestasi siswa yang mengikuti ekstrakurikuler karya ilmiah remaja menjadi daya tarik untuk calon peserta didik dan wali murid.

b. Aspek terhadap setiap orang dialksanakan melalui proses evaluasi yang melibatkan semua pihak yang terlibat, mulai dari wakil kepala sekolah bagian kesiswaan, koordinator ekstrakulikuler, pembina, hingga tim karya ilmiah.

c. Manajemen berdasarkan fakta dalam manajemen mutu ekstrakurikuler karya ilmiah adalah evaluasi terhadap pembina ekstrakurikuler apakah sudah melaksanakan sesuai dengan jadwal yang diberikan koordinator ekstrakurikuler, bagaimana cara melakukan bimbingan kepada tim karya ilmiah, dan target yang dicapai. Sehingga perlu adanya evaluasi untuk mempersiapkan kembali dari awal.

d. Perbaikan berkesinambungan manajemen mutu ekstrakurikuler karya ilmiah di SMA Muhammadiyah 1 Taman melihat kembali program kerja ekstrakurikuler karya ilmiah yang sudah di buat sudah sesuai dengan target atau masih jauh dari harapan. Evaluasi dilakukan oleh pembina ekstrakurikuler dan koordinator ekstrakurikuler beserta wakil kepala sekolah bidang kesiswaan apakah sudah puas dengan hasil prestasi yang didapatkan. Mengajak perbaikan secara berkala kepada tim karya ilmiah yang pernah mengikuti kompetisi.

Berdasarkan penerapan manajemen mutu ekstrakurikuler karya ilmiah mulai dari perencanaan, pelaksanaan maupun evaluasinya didapatkan peningkatan prestasi yang di hasilkan tim karya ilmiah di SMA Muhammadiyah 1 Taman Sidoarjo selama 
tahun ajaran 2019-2020 (Tabel 1). Hal tersebut sesuai dengan penelitian dari ${ }^{10}$ bahwa manajemen ekstrakurikuler karya ilmiah yang baik akan berdampak positif pada prestasi ilmiah siswa dan juga dikenal baik oleh masyarakat. Selain itu pengelolaan atau manajemen ekstrakurikuler yang baik juga akan berdampak baik terhadap peningkatan kualitas dari sekolah tersebut ${ }^{11}$.

Tabel 1. Prestasi Siswa Karya Ilmiah Remaja betdasarkan penerapan manajemen mutu ekstrakurikuler karya ilmiah

\begin{tabular}{lllll}
\hline No & \multicolumn{1}{c}{ Jenis Lomba } & Tingkat & Nama Siswa & Juara \\
& & & & \\
\hline $\mathbf{1}$ & Untag Creative Idea Student & Propinsi & 1. Arsyita Intan Amalia & Juara 1 \\
& $\begin{array}{l}\text { Essay Competition } \\
\text { September 2019 }\end{array}$ & & 2.Eva Avicenna & \\
& & &
\end{tabular}

\begin{tabular}{l|l|l|ll|l}
\hline $\mathbf{2}$ & $\begin{array}{l}\text { Muhammadiyah Education } \\
\text { Awards (ME Award) Karya } \\
\text { Tulis Ilmiah 21 September } \\
\text { 2019 UMM }\end{array}$ & $\begin{array}{l}\text { 1.Aisyah Ramadhanti } \\
\text { Suhada }\end{array}$ & Juara 2 \\
\hline $\mathbf{3}$ & $\begin{array}{l}\text { Muhammadiyah Education Nasional } \\
\text { Awards (ME Award) Karya }\end{array}$ & & Awards \\
& Tulis Ilmiah 21 September \\
& 2019 UMM
\end{tabular}

\begin{tabular}{|c|c|c|c|c|}
\hline 4 & $\begin{array}{l}\text { Karya Tulis Ilmiah Galaksi } \\
\text { Universitas Negeri Surabaya } \\
\text { di Kampus FMIPA } 26 \\
\text { Oktober 2019 tingkat } \\
\text { Nasional }\end{array}$ & Nasional & $\begin{array}{l}\text { 1.Jasmine Qodiah } \\
\text { Roseva } \\
\text { 2.Aisyah Rahmadhanti } \\
\text { Suhada } \\
\text { 3.Fitri Yulinar Ardhila }\end{array}$ & Juara 2 \\
\hline 5 & $\begin{array}{l}\text { Karya Tulis Ilmiah Science } \\
\text { Writing Competition } 2019 \text { se } \\
\text { Jawa Bali di Unesa } 27\end{array}$ & $\begin{array}{l}\text { Se Jawa } \\
\text { dan Bali }\end{array}$ & $\begin{array}{l}\text { 1.Arsyita Intan Amalia } \\
\text { 2.Akbar Krisna } \\
\text { Wandana }\end{array}$ & $\begin{array}{c}\text { Harapa } \\
\text { n } 1\end{array}$ \\
\hline
\end{tabular}

\footnotetext{
${ }^{10}$ Lisaniyah (2019)

${ }^{11}$ Irma Septiani and Bambang Budi Wiyono, 'Manajemen Kegiatan Ekstrakurikuler Dalam Meningkatkan Kualitas Sekolah', Jurnal Manajemen Pendidikan, 23.5 (2012), 424-33.
} 
Oktober 2019

3.Amanda Reza Andriani

\begin{tabular}{|c|c|c|c|c|}
\hline 6 & $\begin{array}{lrr}\text { Olimpicad } & \text { VI } & \text { Semarang } \\
\text { Nasional } & \text { (Karya Ilmiah } \\
\text { Remaja } & \text { Olympicad } \\
\text { Semarang) } & \text { 28 Oktober 2019 }\end{array}$ & Nasional & $\begin{array}{l}\text { 1.Bunga Okta Prihandini } \\
\text { 2. Annisa'ul Baroroh }\end{array}$ & $\begin{array}{l}\text { Juara } 3 \\
\text { Silver } \\
\text { Medali }\end{array}$ \\
\hline 7 & $\begin{array}{l}\text { Essay tingkat Nasional dalam } \\
\text { acara Moeslem Youth } \\
\text { Competition Pesantren UII } \\
\text { Yogyakarta } 2019\end{array}$ & Nasional & $\begin{array}{l}\text { 1.Arsyita Intan Amalia } \\
\text { 2.Bunga Okta Prihandini }\end{array}$ & Juara 3 \\
\hline 8 & $\begin{array}{l}\text { LKTI di Universitas PGRI } \\
\text { ADI BUANA Surabaya } 25 \\
\text { November } 2019\end{array}$ & Propinsi & $\begin{array}{l}\text { 1.Arsyita Intan Amalia } \\
\text { 2.Bunga Okta Prihandini }\end{array}$ & Juara 2 \\
\hline 9 & $\begin{array}{l}\text { AKSARA Inovasi dan } \\
\text { Strategi } \\
\text { Indonesia Sehat Jiwa dalam } \\
\text { Era Digital oleh BEM } \\
\text { FIKES UMM } \\
24-25 \text { Januari } \\
2020\end{array}$ & Nasional & $\begin{array}{l}\text { 1.Fitri Yulinar Ardhila } \\
\text { 2.Jasmine Qodiah } \\
\text { Roseva } \\
\text { 3.Agustina Rahma W. }\end{array}$ & Juara 3 \\
\hline 10 & $\begin{array}{l}\text { AISEF (Asean Innovative } \\
\text { Science and Enginering Fair) } \\
2020\end{array}$ & Asean & $\begin{array}{l}\text { 1.Aisyah Ramadhanti } \\
\text { Suhada } \\
\text { 2. Arsyita Intan Amalia } \\
\text { 3.Bunga Okta Prihandini }\end{array}$ & $\begin{array}{l}\text { Brone } \\
\text { Medal }\end{array}$ \\
\hline
\end{tabular}

\section{KESIMPULAN}

Penerapan manajemen mutu ekstrakurikuler karya ilmiah di SMA Muhammadiyah 1 Taman dilakukan secara tersusun dengan melibatkan berbagai komponen yang ada di sekolah. Penerapan manajemen ekstrakurikuler karya ilmiah meliputi perencanaan, pelaksanaan dan evaluasi dilakukan berdasarkan manajemen mutu dari Edward Sallis yaitu kepuasan pelanggan, aspek terhadap setiap orang, manajemen berdasarkan fakta, dan perbaikan berkesinambungan. Hal tersebut sejalan 
dengan pilar dari visi SMA Muhamamdiyah 1 Taman yaitu Excellent Quality Academic atau kualitas akademik yang baik dan berwawasan global.

\section{DAFTAR PUSTAKA}

Ghafur, A. Hanief Saha, Manajemen Penjaminan Mutu Perguruan Tinggidi Indonesia: Suatu Analisis Kebijakan (Jakarta: Bumi Aksara, 2008)

Inriyani, Yayan, Wahjoedi Wahjoedi, and Sudarmiatin Sudarmiatin, 'Peran Kegiatan Ekstrakurikuler Untuk Meningkatkan Prestasi Belajar IPS', Prosiding Seminar Nasional Mahasiswa Kerjasama Direktorat Jenderal Guru Dan Tenaga Kependidikan Kemendikbud, 1

<https://doi.org/http://pasca.um.ac.id/conferences/index.php/gtk/article/do wnload/246/233>

Lisaniyah, Fashihatul, 'Manajemen Ekstrakurikuler Karya Ilmiah Remaja (Studi Kasus Man 2 Lamongan)', 13.2 (2019), 22-35

Mukhid, Abd., 'Meningkatkan Kualitas Pendidikan Melalui Sistem Pembelajaran Yang Tepat', Tadrîs, 2.1 (2007), 120-33

Mustari, Mohamad, D Ph, M Taufiq Rahman, and D Ph, Manajement Pendidikan, RajaGrafika Persada, 2014

Sallis, Edward, Total Quality Management in Education: Third Edition, Total Quality Management in Education: Third Edition, 2014 <https://doi.org/10.4324/9780203417010>

Septiani, Irma, and Bambang Budi Wiyono, 'Manajemen Kegiatan Ekstrakurikuler Dalam Meningkatkan Kualitas Sekolah', Jurnal Manajemen Pendidikan, 23.5 (2012), 424-33

Smamita, 'Visi Misi SMA Muhamamdiyah 1 Taman', Smamita.Ac.Id, 2018

Supriyanto, Adi, 'Apa Makna Yang Terkandung Di Dalam Surat Az Zalzalah', Https:/ / Www.Dictio.Id, 2018

Syarifuddin, Syarifuddin, 'Total Quality Manajement (TQM) Sebagai Manajemen Mutu Alternatif Pada Program Studi Pendidikan Bahasa Arab', Http://EJournal.Iain-Palangkaraya.Ac.Id, 2011, 21-34 